\title{
Ecology of malaria vector Anopheles culicifacies in a malarious area of Sistan va Baluchestan province, south-east Islamic Republic of Iran
}

H. Vatandoost, ${ }^{1}$ S. N. Emami, ${ }^{7}$ M.A. Oshaghi, ${ }^{1}$ M.R. Abai, ${ }^{1}$ A. Raeisi, ${ }^{2}$ N. Piazzak, ${ }^{3}$ M. Mahmoodi, ${ }^{4}$ K. Akbarzadeh ${ }^{7}$ and M. Sartipi ${ }^{5}$

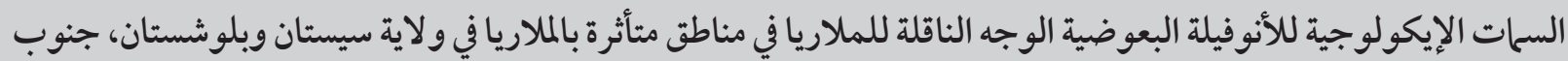

$$
\begin{aligned}
& \text { شرق جمهورية إيران الإسلامية } \\
& \text { حسن وطن دوست، نوشين إمامي، محمد علي عشاقي، محمد رضا عبائي، أحمد رئيسي، نور بيازك، محمود محمو دي، كامران أكبرزاده، محمد سرتيبي }
\end{aligned}
$$

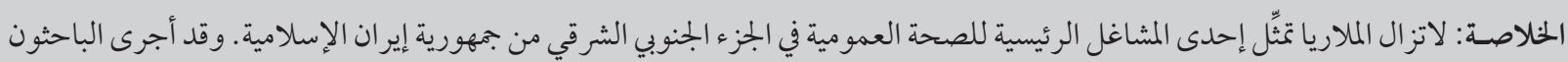

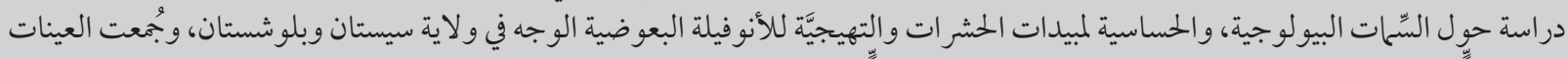

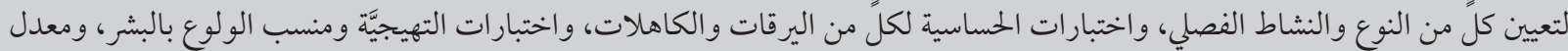

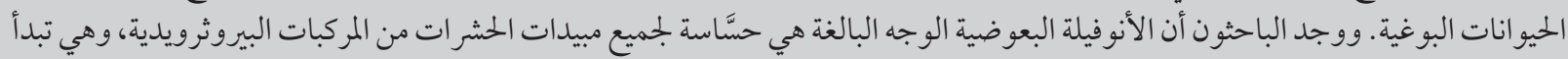

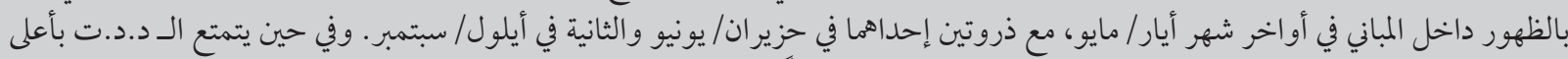

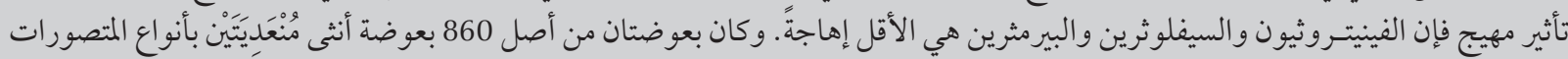

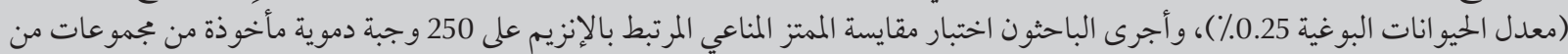

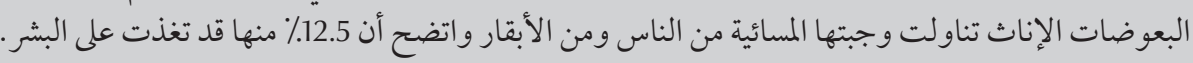

ABSTRACT A study was done of the bionomics, insecticide susceptibility and irritability status of Anopheles culicifacies in Sistan va Baluchestan province. Sampling was performed to determine the following parameters: species identification, seasonal activity, adult and larval susceptibility tests, irritability tests, anthropophily index and sporozoite rate. An. culicifacies adults were susceptible to all tested pyrethroid insecticides. An. culicifacies started to appear indoors in late May, showing 2 peaks in June and September. Fenitrothion, cyfluthrin and permethrin had the least irritancy effect and DDT the highest. Only 2/860 females tested were infected with Plasmodium spp. (sporozoite rate: $0.25 \%$ ). ELISA testing of 250 blood meals derived from night-biting collections of female mosquitoes from humans and cows revealed that only $12.5 \%$ were human-fed.

Écologie du vecteur du paludisme Anopheles culicifacies dans une région impaludée de la province du SistanBaloutchistan, au sud-est de la République islamique d'Iran

RÉSUMÉ Une étude de la bionomie d'Anopheles culicifacies, de sa sensibilité et de son irritabilité aux insecticides a été conduite dans la province du Sistan-Baloutchistan. Des échantillons ont été prélevés pour déterminer les paramètres suivants : identification des espèces, activité saisonnière, test de sensibilité des adultes et des larves, tests d'irritabilité, indice d'anthropophilie et indice sporozoïtique. Les An. culicifacies adultes étaient sensibles à tous les insecticides pyréthroïdes testés. Des individus de l'espèce An. culicifacies commençaient à être observés dans les bâtiments vers la fin du mois de mai avec deux pics, un en juin et un en septembre. Le fénitrothion, la cyfluthrine et la perméthrine avaient le pouvoir irritant le plus faible, à l'opposé du dichlorodiphényltrichloroéthane (DDT) qui était le plus irritant. Seules deux femelles sur les 860 analysées étaient infectées par Plasmodium spp. (indice sporozoïtique : 0,25\%). L'analyse par la technique ELISA de 250 repas de sang provenant de piqûres nocturnes par des moustiques femelles sur des humains et des vaches a révélé que seuls $12,5 \%$ des repas étaient composés de sang humain.

${ }^{7}$ Department of Medical Entomology and Vector Control; ${ }^{4}$ Department of Biostatistics, School of Public Health and National Institute of Health Research, Tehran University of Medical Sciences, Tehran, Islamic Republic of Iran (Correspondence to H. Vatandoost: hvatandoost@yahoo.com). ${ }^{2}$ Malaria Department, Ministry of Health and Medical Education, Tehran, Islamic Republic of Iran. 


\section{Introduction}

Malaria remains a major public health concern in the south-east of the Islamic Republic of Iran in the provinces of Sistan va Baluchistan, Hormozgan and the tropical areas of Kerman provinces, where it is characterized as "refractory malaria”. About $80 \%$ of all malaria cases in the country occur here $[1,2]$. The pattern of malaria is unstable, with 2 seasonal peaks, primarily in the spring and autumn, with outbreaks usually occurring after the rainy season. Although 6 anopheline mosquitoes are known to be the malaria vectors in the southeast Islamic Republic of Iran (Anopheles culicifacies, An. stephensi, An. dthali, An. fluviatilis, An. superpictus and An. pulcherrimus) [3-18], An. culicifacies is the major vector. Its relative density is high even at altitudes up to $3000 \mathrm{~m}$. Studies of its feeding behaviour show that $A n$. culicifacies is predominantly zoophilic, feeding mainly on cattle (anthropophilic index less than 10\%), but where cattle are scarce, its anthropophilic index can reach in excess of $20 \%$ [19].

Traditionally, the sporozoite rate of mosquitoes was assessed by dissection of the salivary glands of individual mosquitoes; however, this is often a laborious process [20]. In recent years more efficient sporozoite detection methods have been developed, including serological methods, e.g. enzyme linked immunosorbent assay (ELISA) or immunochromatographic assay [21] and molecular techniques, e.g. polymerase chain reaction (PCR) [22]. PCR methods have been used to amplify specific DNA sequences of $P$. falciparum for highly sensitive detection of mosquito resident parasites [22]. The PCR procedure can detect as few as 10 sporozoites in the salivary glands ( $0.2 \mathrm{pg}$ of parasite DNA) and is therefore a poweful tool for screening small numbers of anophelines [23].

There are important differences in the bionomics of An. culicifacies in different regions, including differences in seasonal relative density, diurnal activity and human-biting behaviour [24]. Knowledge of the profile of An.culicifacies in different areas of the Islamic Republic of Iran is crucial for understanding the impact of mosquito control strategies that rely principally on indoor spraying of houses with residual insecticide. The objective of this study therefore was to determine the bionomics, insecticide susceptibility and irritability status of An. culicifacies in Sistan va Baluchestan province, south-east Islamic Republic of Iran.

\section{Methods}

\section{Study area}

The investigation was carried out over a period of 12 months in Sistan va Baluchestan province $\left(25^{\circ} 3^{\prime}\right.$ to $28^{\circ} 31^{\prime} \mathrm{N}$ and $58^{\circ} 48^{\prime}$ to $63^{\circ} 19^{\prime} \mathrm{E}$ ) during 2005 . This province has a subtropical climate and is prone to season al malaria transmission. The province comprises 3 regions of differing geography: the coastal region in the south, a mountainous region in the west and the desert region in the east and north. It is bordered by the Oman Sea in the south.

Iranshahr district is located in the centre of Sistan va Baluchestan province with a surface area of $30230 \mathrm{~km}^{2}$, between long $58^{\circ} 59^{\prime}$ to $61^{\circ} 15^{\prime} \mathrm{E}$ and lat $26^{\circ} 55^{\prime}$ to $28^{\circ} 40^{\prime} \mathrm{N}$. The area is subtropical and suitable for malaria maintenance and transmission. Iranshahr is a city with a population of 259700 . The total number of malaria cases was about 7228 in 2005 [personal communication, Iranian Health Ministry disease management centre]. It is an agricultural region irrigated by rivers, deep wells and cement pools, which are the main breeding sites for mosquitoes.

Based on these criteria and from a statistical point of view, several localities in each region were randomly selected for the survey: Bandan, Machkor and Seraydan from the mountainous region and Abchekan, Nokjoob and
Malekabad from the plateau. These sites have been the principal malarious zones in the province in the last 3 years. During the fieldwork, Machkor from the mountainous region and Malekabad from the plateau were omitted from the study due to transport problems and natural disasters such as flooding.

\section{Adult and larval collection methods}

Pyrethrum space spray catches were performed monthly in 8 shelters (4 human and 4 animal shelters) located in different parts of the villages in each region by standard methods using $0.2 \%$ pyrethrum spray [25]. The density was calculated as the number of mosquitoes per shelter. Attempts were also made to catch anophelines outdoors using shelter pits, night catch and window traps.

Larvae were sampled using standard dippers $(500 \mathrm{~mL})$ from breeding places close to adult collection sites. The mean number of larvae was calculated per 10 dippers.

\section{Entomological survey}

Entomological evaluations were carried out in the villages in which malaria transmission occurs and where the presence of An culicifacies had been reported previously. Space-spray collections were carried out monthly in 8 fixed shelters: 4 animal and 4 human shelters in each village, according to World Health Organization $(\mathrm{WHO})$ procedures [26]. In addition, larval collections, night biting and shelter pit collections of adults were carried out monthly and continued for a period of just over 5 months.

\section{Adult susceptibility tests}

The insecticide susceptibility tests on fieldadultsandlarvaewere performed on the An. culicifacies collected from mountainous area. For the adult tests, female Anopheles spp. reared from collected larvae were exposed to discriminating doses of etofenprox $0.50 \%$, permethrin $0.75 \%$, deltamethrin $0.05 \%$, lambdacyhalothrin $0.05 \%$ and cyfluthrin $0.15 \%$ 
for $60 \mathrm{~min}$. at $25-29^{\circ} \mathrm{C}$ and $65 \%-80 \%$ relative humidity [27]. The effects of these insecticides were studied in accordance with WHO standards, using mortality rates after 1-hour exposure followed by monitoring over a 24-hour recovery period [28]. Silicon oil impregnated papers were used for control exposures for pyrethroid insecticides.

\section{Larval susceptibility test}

For the larval insecticide susceptibility tests fenitrothion was used at the discriminating dose. Butanone 2\% in absolute ethanol was used as a control. Late third and early fourth instar larvae were tested with larvicides according to the method described by WHO [29]. The larvae were exposed to discriminative dose of larvicide. A total of 100 larvae representing 4 replicates of 25 larvae were tested. The larvae were fed with Bemax and fish food, and mortality counts were made after a 24-hour exposure period.

\section{Irritability tests}

The irritability levels of An. culicifacies against diagnostic dose of dichlorodiphenyltrichloroethane (DDT) and pyrethroids (lambda-cyhalothrin, permethrin, cyfluthrin and deltamethrin) insecticides were measured in an exposure chamber according to $\mathrm{WHO}$ methods using light intensity of approximately 8 foot candles was used [30]. The field mosquitoes were collected from different larval breeding places of Iranshahr county. In each test, 30 sugar-fed 2-3-day-old adult females were exposured and the number of takeoffs at $1 \mathrm{~min}$. intervals was recorded. for 15 min. The Abbott formula was used to correct the observed mortalities [31]. The results were subjected to statistical analysis using SPSS, version 13 and the collected data were analysed by Student $t$-test and the chi-squared test.

\section{Host preference pattern}

To determine the host preference pattern of An. culicifacies, blood-fed mosquitoes were collected by suction tube inside human dwellings, stables, storerooms and outdoor resting places around villages. The blood meals of the identified anophelines were smeared on circles of Whatman no.1 filter paper. They were interleaved with nonabsorbent onionskin paper and sent to the Department of Parasitology in the Pasteur Institute of Iran for ELISA testing [32].

\section{Detection of malaria parasites}

Investigation of malaria parasites were performed on 860 fed female $\mathrm{An}$. culicifacies mosquitoes (head and thorax) that were collected during 2 malaria transmission peaks: June/July and September/October 2005. Parasite DNA was extracted by phenol-chloroform solution (1:1). Following DNA extraction, nested PCR was conducted due to the high sensitivity of this method for detecting the human malaria parasite [33]. Extracted DNA was processed by the genus-specific primers corresponding to small subunit ribosomal ribonucleic acid (ssr RNA) from malaria parasites such as $P$. vivax and $P$. falciparum [33]. The amplified DNA products were detected in ethidium bromide stained $2.5 \%$ agarose gels using electrophoresis [33].

\section{Results}

\section{Entomological survey}

An. culicifacies were found in all rural districts inspected. Larvae were found in man-made water collections (including wells, cisterns, fountains, ornamental ponds and in the water stored in drums and building construction sites); from pools, stream margins, catch basins and seepage canals; sewage water, wells and the drainage containers of air conditioners in houses. In rural areas, An. culicifacies were found in pools, stream beds, palm irrigation canals, at the margins of stream and rivers, in seepage and in marshy areas with a gentle flow of water.

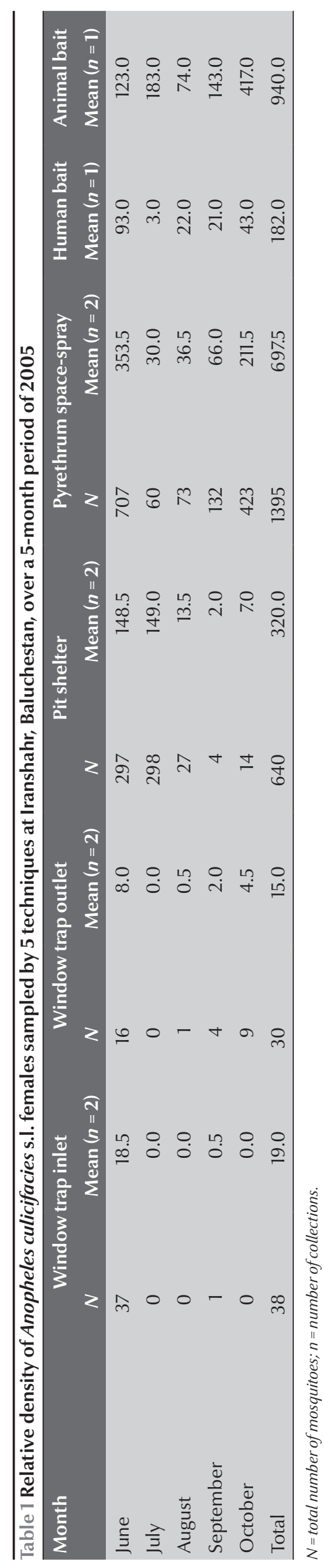


They were also found in water with a high salinity.

In the mountainous area, $\mathrm{An}$. culicifacies were found together with $A n$. fluviatilis, An. dthali, An. hyrcanus, An. superpictus, An. turkhudi and An. stephensi. In the plain regions, this species was found with An. dthali, An. turkhudi, An. stephensi, An. fluviatilis, An. superpictus and An. sergentii.

Table 1 shows the relative densities of An culicifacies s.l. females $(n=3325)$ sampled by the 5 techniques. Pyrethrum indoor space-spray was the most productive sampling method, collecting $52.7 \%$ of the total number of mosquitoes analysed. The window-trap method was not the most suitable method. The results demonstrate the 2 peaks of $A n$. culicifacies mosquito activities in June/ July and September/October.

The abdominal conditions of $A n$. culicifacies $(n=2103)$ using different methods of collection are shown in Table 2. From this table it can be concluded that most females were freshly fed (42.4\%), gravids or semi-gravids.

\section{Seasonal pattern}

This species remained reproductively active throughout 5 months in the province (Figure 1). Its activity started in June, reached a peak in July and then gradually decreased. Subsequently, its relative density again increased from September in the mountainous and plain regions, with a second peak in October. The density of An. culicifacies in mountainous areas was higher in the autumn. There was low activity during the cold winter and hot summer periods.

\section{Host preference pattern}

The host preference pattern of $\mathrm{An}$. culicifacies is presented in Figure 2. Night biting collections resulted in more than 940 specimens from animal bait (cows) and 182 from human bait. This showed that An. culicifacies was highly zoophilic in the rural mountainous areas and in the rural plains.

In ELISA testing of 550 blood meals of this species, the proportion giving positive reactions from $(+)$ to $(++++)$ with alkaline phosphatase anti-human conjugate varied between collection sites. Of those collected $12.5 \%$ had fed on humans alone. All of the blood meals gave a detectable reaction to one or other of the antisera.

\section{Susceptibility tests}

The results of larval susceptibility tests showed that diagnostic doses of fenitrothion caused $100 \%$ mortality of larvae of An. culicifacies after a 24-hour recovery period.

The adult susceptibility tests using WHO criteria (98\%-100\% mortality indicating susceptibility and $<98 \%$ mortality indicating resistance), showed that An. culicifacies was susceptible to all the insecticides tested: etofenprox, permethrin, deltamethrin, lambdacyhalothrin and cyfluthrin.

\section{Irritability tests}

The results of irritability tests showed that DDT had the most irritancy effect against An. culicifacies whereas permethrin and cyfluthrin displayed the lowest irritancy effect. The mean number of take-offs/minute/adult with permethrin was 0.58 (SD 0.08). The figures for DDT, deltamethrin, lambdacyhalothrin, cyfluthrin and etofenprox were: 4.47 (SD 0.33), 0.77 (SD 0.09), 0.92 (SD 0.11), 0.73 (SD 0.10) and 1.54 (SD 0.15) respectively. Using one-way analysis of variance and the GamesHowell post-hoc test, the results showed a statistically significant difference in the irritability level among pyrethroids, with permethrin showing a higher irritancy in An. culicifacies compared with DDT, lambda-cyhalothrin, cyfluthrin and deltamethrin $(\mathrm{P}<0.05)$.

\section{Detection of malaria parasites}

The analysis of malaria parasites revealed that out of 860 An. culicifacies females tested, 2 samples were infected by Plasmodium spp, a sporozoite rate of $0.25 \%$.

\section{Discussion}

Mosquitoes of the An. culicifacies complex are widespread in tropical Asia and are the principle vectors of malaria across the Indian sub-continent and Arabian peninsula, including parts of the Islamic Republic of Iran. An. culicifacies occurs in scattered foci along the Gulf area as far west as Bushehr, in the south of the Islamic Republic of Iran. An. culicifacies Giles with An. stephensi is regarded as the chief vector of malaria in the south-eastern corner of Islamic Republic of Iran [34]. In most areas the An. culicifacies s.l. population have 2 main seasonal peaks of relative density, during the spring and autumn $[35,36]$. We too found the main peak in June and a

\begin{tabular}{|c|c|c|c|c|c|c|c|c|c|}
\hline \multirow[t]{2}{*}{ Source of collection } & \multirow{2}{*}{$\begin{array}{l}\text { No. } \\
\text { tested }\end{array}$} & \multicolumn{2}{|c|}{ Unfed } & \multicolumn{2}{|c|}{ Freshly fed } & \multicolumn{2}{|c|}{ Semi-gravid } & \multicolumn{2}{|c|}{ Gravid } \\
\hline & & No. & $\%$ & No. & $\%$ & No. & $\%$ & No. & $\%$ \\
\hline Window trap & 68 & 31 & 45.5 & 37 & 54.4 & 14 & 21.1 & 13 & 19.1 \\
\hline Pit shelter & 640 & 305 & 47.6 & 335 & 52.3 & 86 & 13.5 & 102 & 15.9 \\
\hline Pyrethrum space-spray & 1395 & 877 & 62.9 & 520 & 37.3 & 423 & 30.3 & 342 & 24.5 \\
\hline Total & 2103 & 1213 & 57.6 & 892 & 42.4 & 523 & 24.9 & 457 & 21.7 \\
\hline
\end{tabular}




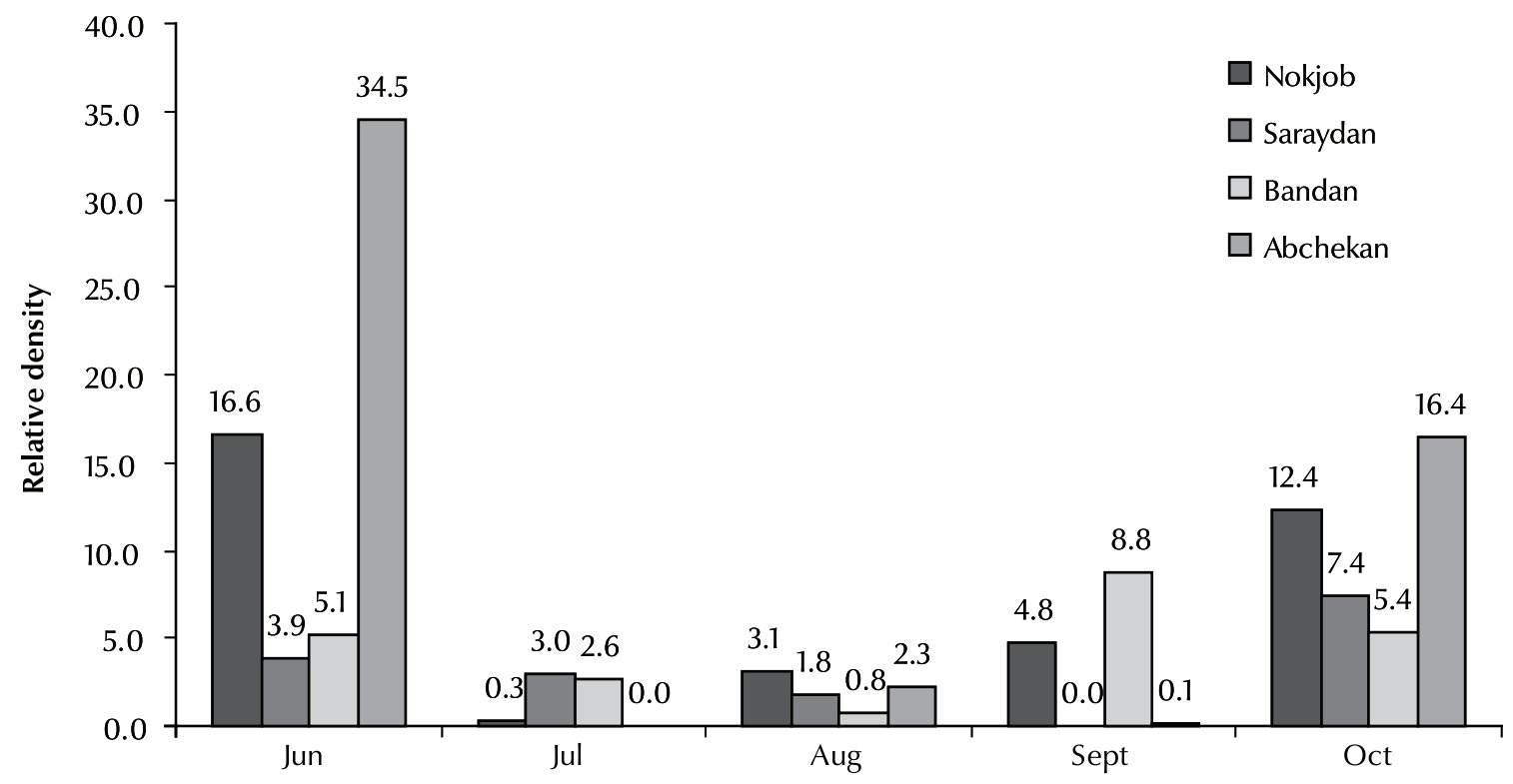

Month of collection

Figure 1 Relative density of Anopheles culicifacies in different rural areas of Sistan va Baluchestan province using the total catch method

secondary peak in October. Iranshahr district, including our unsprayed study villages, is a major rice-growing area of Baluchistan where, during April to September, irrigated rice is the main breeding source of An. culicifacies s.l., along with irrigated palms and stream pools. During the winter months, from
October to April, stream pools serve as the predominant breeding sites of $A n$. culicifacies s.l.in the majority of areas [34]. Further studies are needed to determine the aestivation and hibernation habits of this species in winter conditions.

An.culicifaciess.l.hasbeenregardedas mainly endophilic [37], with outdoor- resting behaviour reported recently in some parts of India [38]. In this study, pyrethrum space-spray indoors was the most productive sampling method for An. culicifacies s.l. The results are consistent with those obtained in a previous study in this part of Islamic Republic of Iran [34]. Nevertheless,

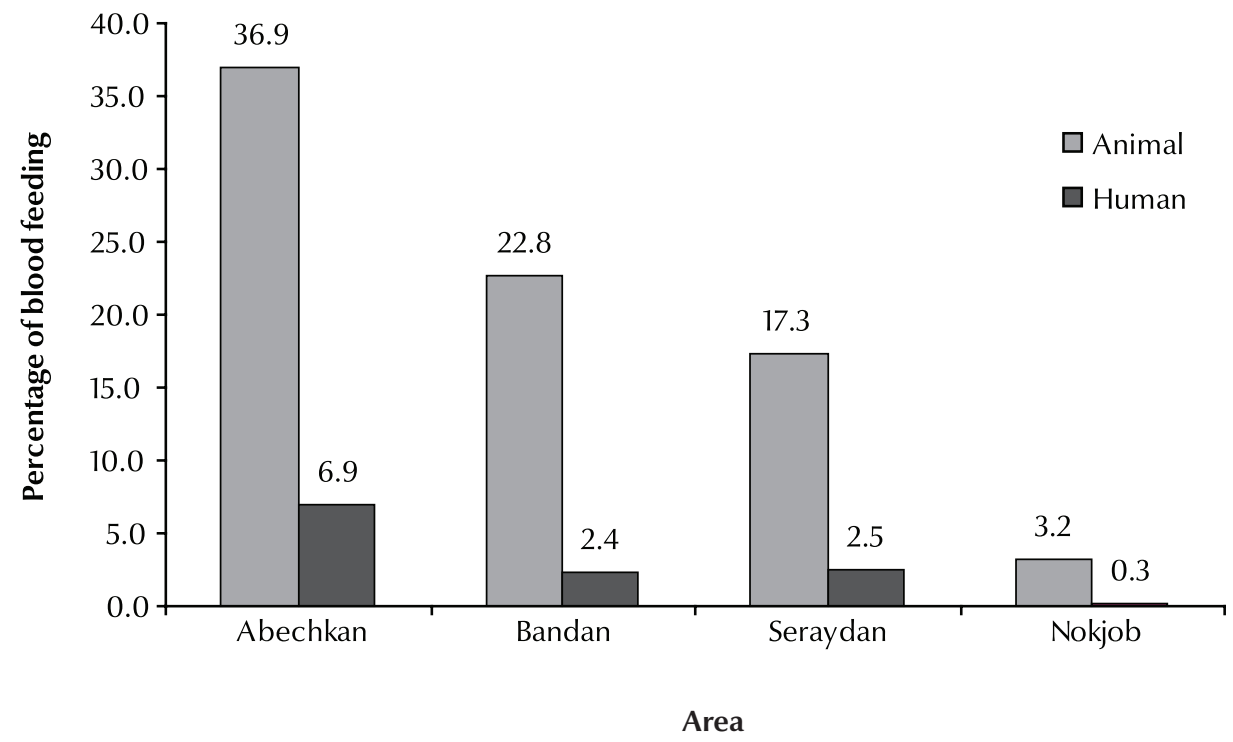

Figure 2 Host preferences of Anopheles culicifacies in 4 different rural areas of Sistan va Baluchestan province ( $n=940$ from animal bait; $\boldsymbol{n}=182$ from human bait) 
our study found considerable numbers of An. culicifacies s.l. resting outdoors in caves and pit shelters. Our analysis of abdominal conditions from females caught from pyrethrum space-spray, window trap and pit shelters showed that most were freshly-fed gravids or semi-gravids.

In field populations of the malaria vectors An. culicifacies and An. subpictus at a village in the low country of Sri Lanka during 1994-96, analysis of blood meals by ELISA showed that $8.3 \%$ of $242 \mathrm{An}$. culicifacies were human-fed and $80 \%$ of these (i.e. 6.6\%) were concurrently bovid-fed [39]. These figures are much lower than the usual human blood index for afrotropical malaria vectors [40].
In our study the host preference pattern of An. culicifacies showed that $12.5 \%$ had fed on humans alone.

Irritability tests showed that An. Culicifacies adults were susceptible to all the insecticides tested and that irritability to permethrin was significantly lower than for DDT, lambdacyhalothrin, cyfluthrin and deltamethrin. There are different sibling species of An. culicifacies in the world, for instance occurrence of sibling species $A, B, C, D$ and $E$ from India [41] $A$ and $B$ from Islamic Republic of Iran [42], B and E from Sri Lanka [43]. This species has several sibling species in the south-eastern part of the Islamic Republic of Iran and each sibling seems to have a different behavioural response.
The PCR procedure can detect as few as 10 sporozoites in the salivary glands (0.2 pg of parasite DNA) and is therefore a useful tool for screening small numbers of anophelines [23]. The infectivity rate among An. culicifacies females was very low $(0.25 \%)$ in the season in which our samples were collected. This method has proved to be more sensitive than other diagnostic methods and is recommended for epidemiological studies in different malarious regions of the country.

We aim to establish a national laboratory for the detection of parasites in malaria vector mosquitoes using the molecular method described in our study.

\section{References}

1. Manouchehri AV, Zaim M, Emadi AM. A review of malaria in Iran, 1975-90. Journal of the American Mosquito Control Association, 1992, 8:381-385.

2. Zaim M. Malaria control in Iran-present and future. Journal of the American Mosquito Control Association, 1987, 3:392-396.

3. Vatandoost H. Irritability level of Anopheles sephensi in Iran, 2001. Iranian Journal of Public Health, 2004, 30:27-30.

4. Vatandoost $\mathrm{H}$, Vaziri VM. Larvicidal activity of a neem tree extract (Neemarin) against mosquito larvae in the Islamic Republic of Iran. Eastern Mediterranean Health Journal, 2004, 10:573-581.

5. Vatandoost $\mathrm{H}$ et al. Larval habitats of main malaria vectors in Hormozgan province and their susceptibility to different larvicides. Southeast Asian Journal of Tropical Medicine and Public Health, 2004, 35(Suppl. 2):22-25.

6. Vatandoost $\mathrm{H}$ et al. Monitoring of insecticides resistance in main malaria vectors in a malarious area of Kahnooj district, Kerman province, southeastern Iran. Journal of Vector Borne Diseases, 2005, 42:100-108.

7. Vatandoost $\mathrm{H}$, Hanafi-Bojd AA. Current resistant status of Anopheles stephensi Liston to different larvicides in Hormozgan province, southeastern Iran. Pakistan Journal of Biological Sciences, 2005, 8:1568-1570.

8. Hanafi-Bojd AA, Vatandoost H, Jafari R. Susceptibility status of Anopheles dthali and An. fluviatilis to commonly used larvicides in an endemic focus of malaria, southern Iran. Journal of Vector Borne Diseases, 2006, 43:34-38.

9. Vatandoost $\mathrm{H}$ et al. Laboratory efficacy of protection rate of torn nets treated with pyrethroids, cufluthrin, deltamethrin and permethrin against Anopheles stephensi (Diptera: Culicidae). Journal of Biological Sciences, 2006, 6:331-336.

10. Vatandoost $\mathrm{H}$ et al. Bionomics of Anopheles stephensi Liston in the malarious area of Hormozgan province, southern Iran, 2002. Acta Tropica, 2006, 97:196-203.

11. Oshaghi MA et al. Effects of post-ingestion and physical conditions on PCR amplification of host blood meal DNA in mosquitoes. Experimental Parasitology, 2006, 112:232-236.
12. Oshaghi MA, Chavshin AR, Vatandoost H. Analysis of mosquito bloodmeals using RFLP markers. Experimental Parasitology, 2006, 114:259-264.

13. Oshaghi MA et al. Anopheles stephensi biological forms, geographical distribution, and malaria transmission in malarious regions in Iran. Pakistan Journal of Biological Sciences, 2006, 9:294-298

14. Enayati AA et al. Molecular evidence for a kdr-like pyrethroid resistance mechanism in the malaria vector mosquito Anopheles stephensi. Medical and Veterinary Entomology, 2003, 17:138-144.

15. Davarai B et al. Comparative efficacy of different imagicides against different strains of Anopheles stephensi in the malarious areas of Iran, 2004-2005. Pakistan Journal of Biological Sciences, 2006, 9:885-892.

16. Zahirnia $\mathrm{AH}$ et al. Insecticide resistance/susceptibility monitoring in Anopheles pulcherrimus (Diptera: Culicidae) in Ghasreghand district, Sistan and Baluchistan province, Iran, 1997. Hakim, 1998, 1:97-106.

17. Zahirnia $\mathrm{AH}$, Taherkhani $\mathrm{H}$, Vatandoost H. Observation of malaria sporozoite in Anopheles culicifacies (Diptera: Culicidae) in Ghasreghand district, Sistan and Baluchistan province. Hakim., 2001, 4:149-153.

18. Naddaf SR et al. Molecular characterization of Anopheles fluviatilis species complex in the Islamic Republic of Iran. Eastern Mediterranean Health Journal., 2003, 9:257-265.

19. Rao RT. The anophelines of India. Delhi, Malaria Research Centre, 1984.

20. Manual on practical entomology in malaria. Part II. Geneva, World Health Organization, 1975 (WHO Offset Publication 13).

21. Wirtz RA et al. Development and evaluation of an enzymelinked immunosorbent assay for Plasmodium vivax-VK247 sporozoites. Journal of Medical Entomology, 1992, 29:854-857.

22. Fucharoen $\mathrm{S}$ et al. Differentiation of Plasmodium falciparum clones by means of a repetitive DNA probe. Transactions of the Royal Society of Tropical Medicine and Hygiene, 1988, 82:209-211. 
23. Tassanakajon A et al. Polymerase chain reaction detection of Plasmodium falciparum in mosquitoes. Transactions of the Royal Society of Tropical Medicine and Hygiene, 1993, 87:273-275.

24. Subbarao SK. The Anopheles culicifacies complex and control of malaria. Parasitology Today, 1988, 4:72-75.

25. Practical entomology in malaria eradication. Part I. Field and Laboratory techniques. Geneva, World Health Organization, 1963 (WHO/PA/62.63, 8-11).

26. Entomological field techniques for malaria control. Part II: tutor's guide. Geneva, World Health Organization, 1992.

27. Test procedure for insecticide resistance monitoring in malaria vectors, bio-efficacy and persistence of insecticides on treated surfaces. Geneva, World Health Organization, 1998 (WHO/CDS/ $\mathrm{CPC} / \mathrm{MAL} / 98.12)$.

28. Instructions for determining the susceptibility or resistance of adult mosquito to organochlorine, organophosphorine and carbamate insecticides-diagnostic test. Geneva, World Health Organization, 1981 (WHO/VBC/81.806).

29. Instructions for determining the susceptibility or resistance of mosquito larvae to insecticides. Geneva, World Health Organization, 1981 (WHO/VBC/81.807).

30. Insecticide resistance and vector control. Seventeenth Report of the WHO Expert Committee on Insecticides. Geneva, World Health Organization, 1970 (WHO Technical Report Series No. 443).

31. Abbott WS. A method of comparing the effectiveness of an insecticide. Journal of Economic Entomology, 1965, 18:265-267.

32. Edrissian GH, Manouchehry AV, Hafizi A. Application of an enzyme-linked immunosorbent assay (ELISA) for determination of human blood index in anopheline mosquitoes collected in Iran. Journal of the American Mosquito Control Association, 1985 13:349-352.

33. Snounou G et al. High-sensitivity of detection of human malaria parasites by the use of nested polymerase chain-reaction. Molecular and Biochemical Parasitology, 1993, 61:315-320.

34. Zaim M et al. Survival rates of Anopheles culicifacies s.l. and Anopheles pulcherrimus in sprayed and unsprayed villages in
Ghassreghand district, Baluchistan, Iran, 1991. Journal of the American Mosquito Control Association, 1993, 9:421-425.

35. Zahar AR. Vector bionomics in the epidemiology and control of malaria. Part II. The WHO European region and the WHO Eastern Mediterranean region. Vol. II. Applied field studies. Section III. Vector bionomics, Malaria epidemiology and control by geographical areas $(B)$ Asia west of India. Geneva, World Health Organization, 1990 (VBC/90.3, MAL/90.3).

36. Reisen WK. A quantitative mosquito survey of 7 villages in Punjab Province, Pakistan, with notes on bionomics, sampling methodology and the effects of insecticides. Southeast Asian Journal of Tropical Medicine and Public Health, 1978, 9:587-601.

37. Rao TR. The anophelines of India. New Delhi, Indian Council for Medical Research, 1981,

38. Tewari SC et al. Space-spraying with malathion as a supplementary measure for operational malaria control. Indian Journal ofMedical Research, 1990, 91:151-158.

39. Amerrasinghe $\mathrm{PH}$, Amerasinghe FP. Multiple host feeding in field populations of Anopheles culicifacies and An. subpictus in Sri Lanka. Medical and Veterinary Entomology, 1999, 13:124-131.

40. Bruce-Chwatt LJ, Garrett-Jones C, Weitz B. Ten years' study (1955-64) of host selection by anopheline mosquitos. Bulletin of the World Health Organization, 1966, 35:405-439.

41. Goswami G et al. PCR-RFLP of mitochondrial cytochrome oxidase subunit II and ITS2 of ribosomal DNA: markers for the identification of members of the Anopheles culicifacies complex (Diptera: Culicidae). Acta Tropica, 2005, 95:92-99.

42. Oshaghi MA, Moradi MT, Taghilo B. Specific detection of malaria parasites using nested- PCR in individual mosquitoes and infected bloods in Chabahar and Iranshar, Iran. Hakim., 2004, 7:24-31.

43. Surendran SN et al. Anopheles culicifacies sibling species B and $\mathrm{E}$ in Sri Lanka differ in longevity and in their susceptibility to malaria parasite infection and common insecticides. Medical and Veterinary Entomology, 2006, 20:153-156. 